\title{
OPINI MASYARAKAT KOTA PASURUAN TENTANG BERITA BEGAL PADA RUBRIK KRIMINAL WARTABROMO.COM
}

\author{
Nur Badriatus Sholicha \\ Program Studi IImu Komunikasi, FISIP, Universitas Yudharta, Pasuruan, Indonesia
}

DayurejoRT/RW:04/01 Prigen Pasuruan 67162

Ryah0411@gmail.com

\begin{abstract}
ABSTRAK
Pemberitaan begal di Kabupaten Pasuruan terkategori memiliki intensitas yang sangat tinggi, hal ini bisa dibuktikan dengan seringnya pemberitaan begal pada beberapa media online di Kabupaten Pasuruan, salah satunya adalah media online www.wartabromo.com. Pemberitaan begal di kabupaten pasuruan dalam kurun waktu satu tahun terakhir periode Januari 2017-Januari 2018 jumlahnya sangat bombastis, dengan jumlah 79 berita begal. Dari seringnya pemberitaan begal ini membuat netizen menyebut pasuruan sebagai "kota begal". melihat persoalan tersebut, menjadi sebuah kekhawatiran bagi warga pasuruan akan keselamatan dirinya dari pembegalan. Hal ini tentunya akan memicu opini masyarakat terhadap pemberitaan tersebut.
\end{abstract}

Dari deskripsi latar belakang tersebut penelitian ini mencoba untuk mengetahui Opini Masyarakat Kota Pasuruan terkait pemberitaan begal pada rubrikkriminal Wartabromo.com, yang mana peneliti akan mengetahui isi opini, arah opini serta intensitas. Penelitian ini menggunakan metode penelitian deskriptif kualitatif dengan fokus penelitian pada opini masyarakat yang ditimbulkan dari intensitas pemberitaan begal pada media Wartabromo.com. Metode pengumpulan data melulaui Wawancara mendalam menggunakan teknik Snowball Sampling pada masyarakat Kota Pasuruan di 4 Kecamatan. Dari penelitian ini diharapkan dapat mengetahui Opini masyarakat Kota Pasuruan tentang berita begal pada rubrik kriminal Wartabromo.com

Berdasarkan hasil pembahasan maka dapat disimpulkan bahwa opini Masyrakat Kota Pasuruan terhadap berita begal pada rubrik Wartabromo.com cenderung positif (Pro) hal ini di buktikan dengan, pertama isi opini, pendapat mereka cenderung pro terhadap pemberitaan begal tersebut. Kedua arah opini, pendapat mereka cenderung pro terhadap berita begal pada rubric criminal Wartabromo.com. ketiga intensitas, ketajaman issue masyarakat kota Pasuruan pada kasus pembegalan sangat kuat. Selain itu diharapkan pemberitaan yang terus menerus diberitakan ini mampu memberikan kritikan terhadap pemerintah bahwasannya Pasuruan saat ini sangat jauh dari kata aman.

Kata Kunci : Masarakat Kota Pasuruan, Pemberitaan Begal, Media Online, Wartabromo.com

\section{ABSTRACT}

The reporting of begal in Pasuruan Regency is categorized as having very high intensity, this can be evidenced by the frequent reporting of online media in Pasuruan Regency, one of which is online media www.wartabromo.com. News coverage in Pasuruan district in the last one year period January 2017-January 2018 was very bombastic, with a total of 79 bad news. From this frequent reporting, netizens call pasuruan a "begal city". looking at the problem, it becomes a concern for the pasuruan residents of their safety from reprimand. This will certainly trigger public opinion on the news.

From the background description, this study tries to find out the opinion of the Pasuruan City Society regarding the reporting on the criminal section of Wartabromo.com, in which researchers will find out the content of opinions, direction of opinion and intensity. This study uses a descriptive qualitative research method with a focus on research on public opinion arising from the intensity of reporting on the media Wartabromo.com. Methods of data collection through in-depth interviews using Snowball Sampling techniques in Pasuruan City communities in 4 Districts. From this research, it is expected to know the opinion of the Pasuruan City community about the news in the crime section of Wartabromo.com

Based on the results of the discussion, it can be concluded that the opinion of the Pasuruan City community on the news in the Wartabromo.com section tends to be positive (Pro), this is evidenced by, first, the content of the opinion, their opinion tends to be pro to the news. Both directions of opinion, their opinions tend to be pro-news about the criminal rubric of Wartabromo.com. third intensity, the sharpness of the issue of the people of Pasuruan city in the case of repression is very strong. Besides that, the news that is continuously reported is expected to be able to give criticism to the government that Pasuruan is currently very far from being safe.

Keywords: Pasuruan City Community, News Begal, Online Media, Wartabromo.com 


\section{PENDAHULUAN}

Pemberitaan begal di Pasuruan terkategori memiliki intensitas yang sangat tinggi, hal ini bisa dibuktikan dengan seringnya pemberitaan begal yang terjadi di lingkup Pasuruan dan diberitakan oleh beberapa media online di Pasuruan, salah satunya adalah media online www.wartabromo.com yang sudah diamati oleh peneliti, pemberitaan begal di Pasuruan dalam kurun waktu satu tahun terakhir telah mencapai jumlah yang bombastis dengan sebanyak 79 berita begal yang ditampilkan. Dari seringnya pemberitaan begal ini menjadikan netizen menyebut Pasuruan sebagai "kota begal". Melihat persoalan tersebut, menjadi sebuah kekhawatiran tersendiri bagi warga pasuruan akan keselamatan dirinya dari pembegalan, karena pemberitaan begal yang terus-menerus diberitakan mampu memunculkan opini masyarakat tentang pemberitaan tersebut.

Pembentukan opini publik sangat bergantung pada proses komunikasi. Masyarakat memperoleh pengetahuan atau informasi tentang persoalan yang terjadi di masyarakat melalui proses komunikasi. Salah satunya adalah melalui media massa. Masalah sekecil apapun bisa berkembang dengan cepat karena pemberitaan melalui media. Media membentuk opini publik untuk membawanya pada perubahan yang

\section{Komunikasi Massa}

Definisi komunikasi massa menurut Joseph A. Devito (Nurudin, 2014:3) adalah komunikasi melalui media massa (media cetak dan elektronik). Sebab, awal perkembangannya saja komunikasi massa berawal dari pengembangan kata media of mass communication (media komunikasi massa). Ada definisi komunikasi massa yang dikemukakan Michael W. Gamble dan Teri Kwal Gamble (1986) akan semakin memperjelas apa itu komunikasi massa. Menurut mereka sesuatu bisa didefinisikan sebagai Komunikasi Massa jika mencakup hal-hal sebagai berikut :

Komunikator dalam komunikasi massa mengandalkan peralatan modern untuk menyebarkan atau memancarkan pesan secara cepat kepada khalayak yang luas dan tersebar. Pesan itu disebarkan melalui media modern pula antara lain surat kabar, majalah, televise, film, atau gabungan di antara media tersebut.

Komunikator dalam komunikasi massa dalam menyebarkan pesan-pesannya bermaksud mencoba berbagai pengertian dengan jutaan orang yang tidak saling kenal atau mengetahui satu sama lain. Anonimitas audience dalam signifikan. Subyek opini publik adalah masalah baru yang bersifat kontroversial. Unsur-unsur opini publik adalah pernyataan yang kontroversial mengenai suatu hal yang bertentangan dan reaksi pertama atau gagasanbaru.

Opinimulaiterbentukketika ada suatu masalah kontroversialdan tidak umumyang munculdiberbagaimedia. Media massa memiliki kemampuan dalam membeberkansuatufaktabahkan membentuk opinimasyarakat. Media massa mampu menggiringi masyarakat untuk beropiniterhadap halyang diberitakan. Berita yang ditampilkan keluar oleh media massa merupakan cara efektif pembentukanopiniatau pendapat umum.Sudahdapatdipastikan bahwa setiap topiktopik beritayang dipublikasikan oleh berbagai media massaitumengandung pembentukan opini. Melalui berita-berita atau pendapatyang berkembang,mempunyai pengaruh terhadap pandangan sesorang bisadiartikan berita-berita yang dipublikasikan itu dapat membentuk opini masyarakat (Ruslan, 2008:66-75).

Melihat fenomena di atas maka peneliti mencoba melakukan penelitian tentang opini masyarakat Kota Pasuruan Tentang Berita Begal Pada Rubrik Kriminal Wartabromo.com.

\section{KAJIAN PUSTAKA}

komunikasi massa inilah yang membedakan pula dengan jenis komunikasi yang lain. Bahkan pengirim dan penerima pesan tidak saling mengenal satu sama lain. Pesan adalah milik public. Artinya bahwa pesan ini didapatkan dan diterima oleh banyak orang. Karena itu, di artikan milik public.

\section{Opini}

Menurut Nimmo dalam Komunikasi Politik : Khalayak dan Efek (2000:3) opini publik digambarkan sebagai proses menggabungkan pikiran, perasaan dan usul yang diungkapkan oleh warga negara secara pribadi terhadap pilihan kebijakan yang dibuat oleh pejabat pemerintah yang bertanggung jawab atas dicapainya ketertiban sosial dalam situasi yang mengandung konflik dan perselisihan pendapat. Arifin dalam Komunikasi Politik Filsafat-Paradigma-TeoriTujuan-Strategi dan Komunikasi Politik Indonesia (2011:193) menyatakan bahwa opini publik adalah pendapat rata-rata individu dalam masyarakat sebagai hasil diskusi tidak langsung yang dilakukan untuk memecahkan persoalan sosial, terutama yang dibuat oleh media massa. Oleh karena itu, opini publik hanya akan terbentuk jika ada isu yang 
dikembangkan oleh media massa (pers, film, radio dan televisi).

Proses pembentukan opini publik yaitu penyesuaian opini pribadi tiap-tiap individu dalam satu kesamaan persepsi tentang opini tersebut. Pada akhirnya, kesamaan persepsi masyarakat Kota Pasuruan merupakan opini publik yang merepresentasikan pemberitaan begal pada rubrik kriminal wartabromo.com. Menurut Dan Nimmo dalam (Riswandi:2009) Berdasarkan tahapan pembentukkan opini publik, karakteristik opini publik dapat dijabarkan sebagai berikut :

Mempunyai isi. Opini adalah tentang sesuatu. Publikasi atas konflik yang berpotensi menjadi isu merupakan isi dari sebuah opini. Dengan kata lain, opini adalah respon aktif yang bermuatan isu atau kabar angin atau apapun itu tentang suatumasalah.

Opini publik mempunyai arah. Sejak proses pembentukan opini publik dimulai, opini publik secara alami akan mengarah (diarahkan atau tidak) pada sebuah keputusan final atas opini publik tersebut, seperti percaya- tidak percaya tentang sosok pemimpin dalam pemilukada, mendukung- menentang diterapkannya UU Pornografi, dansebagainya.

Intensitas menurut Kamus Besar Bahasa Indonesia (KBBI) merupakan keadaan tentang tingkatan atau ukuran. Dalam ranah opini publik, intensitas dapat diartikan sebagai ukuran ketajaman terhadap isu seperti kuat, sedang atau lemah. Semakin kuat isu maka opini publik yang terbentuk akan semakin mengerucut pada sebuah keputusan atas isu tersebut.

Berdasarkan pemaparan teori opini publik di atas, dapat disimpulkan bahwa opini publik merupakan sebuah kegiatan kolektif yang menghasilkan konsensus mengenai sesuatu hal. Di mana opini publik terbentuk melalui tiga tahapan pembentukan dan memiliki karakteristikkarakteristik yang menandainya. Selain itu, opini membutuhkan media publikasi agar dapat berakhir sebagai opini publik.

\section{Media Online}

Media dapat diartikan dengan saluran atau alat, sedangkan online istilah bahasa dalam internet yang artinya sebuah informasi yang dapat di akses dimana saja selama ada jaringan internet. Sudiana (2000) dalam Nurliati (2001)yang dikutip oleh Vini Winarti Halim dalam skripsinya (2006:26), mendefinisikan media online sebagai media pemberitaan yang terbit secara inline di internet.

Menurut buku Jurnalistik Terapan yang ditulis oleh Syarifudin Yunus (2010:7) mengatakan, media online yaitu media internet, seperti wibsite, blog, dan lainnya yang terbit/tayang di dunia maya, dapat dibaca dan dilihat di internet

\section{Berita Kriminal}

Berdasarkan beberapa definisi mengenai kriminal maka dapat diambil kesimpulan pengertian berita kriminal. Berita kriminalyaitu laporan aktual berupa fakta, peristiwa dan pendapat mengenai tindakan kejahatan atau kriminal yang dilakukan seseorang atau kelompok serta melanggar aturan hukum yang ditetapkan. Adapun tindak kejahatan meliputi : pencurian, pemerasan, perampokan, pembunuhan, penganiayaan, perkosaan, pencopetan, penodongan, penipuan dan korupsi.

Berita kejahatan atau yang dikenal dengan nama berita kriminal merupakan berita yang sering ditemukan dalam berbagai media massa. Berita ini biasanya menggunakan kata-kata sensasional sehingga menarik perhatian pembaca. Dalam penyajiannya sering terjadi kontroversial terutama bagi kalangan moralis dan kriminolog. Pers yang mempunyai fungsi penyebar informasi tentunya mempunyai alasan yang tepat dalam menyajikan berita kriminal. Pers bukan mempromosikan kejahatan kepada massa. Melainkan dengan tulisan atau disiarkannya berita kriminal diharapkan masyarakat tidak mau melakukan hal serupa dengan yang diberitakan.

Begal

"Begal" merupakan kata kerja, sinonim kata begal adalah kata penyamun, sementara kata "pembegalan" adalah proses, cara, perbuatan yang berarti perampasan atau perampokan. Secara terminologi kata begal dapat diartikan sebagai sebuah aksi kejahatan (kriminal) seperti perampokan/perampasan yang dilakukan oleh seseorang disertai kekerasan dengan menggunakan senjata tajam dan menggunakan kendaraan bermotor bahkan biasa sampai melakukan pembunuhan terhadap korban dan korban yang disasar biasanya pengendara sepeda motor. Jadi Begal merupakan suatu perbuatan merampas, merampok dengan cara paksa menggunakan kendaraan bermotor dan senjata tajam. dimana begal termasuk kedalam pencurian disertai dengan kekerasan terhadap dalam pasal $365 \mathrm{KUH}$.

\section{METODE PENELITIAN Jenis Penelitian}

Penulis menggunakan jenis penelitian dengan metode kualitatif deskripsi, hal ini disebabkan penulis memiliki tujuan untuk mendeskripsikan 
data secara mendalam dan komprehersif. Hal ini sejalan dengan Moleong (2009:6) yang menyatakan bahwa kualitatif deskriptif mendefinisikan penelitian kualitatif sebagai penelitian yang berusaha memaami fenomena tentang apa yang di alami subyek penelitian secara holistik dan deskripsi dalam bentuk kata-kata serta bahasa pada suatu konteks khusus yang alamiah dan dengan memanfaatkan berbagai metode alamiah.

\section{Fokus Penelitian}

Masalahpada

penelitiankualitatifbertumpupada

suatufokus.Adapunmaksud

merumuskanmasalah

dalam

penelitian

denganjalanmemanfaatkanfokusyaitu pertama,

penetapan fokus dapat membatasi studi; kedua,

penetapan

fokus

berfungsiuntukmemenuhuiinklusi-

inklusiataukriteriamasuk-keluar(inclusion-

exlusioncriteria)atauinformasibaruyang

diperolehdilapangan

sebagaimana

dikemukakanMoleong

(2004:93-

94).Dalammetodekualitatif,fokuspenelitian

berguna

untukmembatasibidanginquiry.Tanpaadanyafokus

penelitian, peneliti

akanterjebakolehbanyaknyadatayang

diperolehdilapangan.Olehkarenaitu

fokus

penelitian akan berperan sangat penting dalam memandang dan mengarahkan penelitian.

Fokuspenelitianbersifattentatifseiring

denganperkembangan penelitian.

Moleong(2009:237)menyatakanbahwa

fokuspenelitiandimaksudkanuntuk membatasi studi kualitatif, sekaligus membatasi penelitian gunamemilih data yang relevan dan yang baik. Dalam penelitian ini, peneliti memfokuskan penelitianpada opini masyarakat pada 4 kecamatan yang ada di Kota Pasuruan terkait Berita Begal Pada Rubrik Kriminal Wartabromo.com.

\section{Unit Analisis}

Unitanalisisadalahmerupakansesuatuyang berkaitandenganfokus yang diteliti. Unit analisis merupakan suatu penelitian yang dapat berupa benda, individu, kelompok, wilayah dan waktu tertentu sesuai denganfokus Penelitian. Pada penelitiankualitatifpada dasarnyaanalisisdata mempergunakan pemikiran logis, analisis dengan logika, dengan induksi, deduksi, analogi, komparasi, dan sejenisnya.

Tabel 3.4 Unit Analisis dan Kategorisasi

\begin{tabular}{|c|c|}
\hline UNIT ANALISIS & KATEGORISASI \\
\hline 1. Isi Opini & $\begin{array}{l}>\text { Kecemasan } \\
>\text { Pujian } \\
>\text { Kritik } \\
>\text { Harapan }\end{array}$ \\
\hline 2. Arah Opini & $\begin{array}{l}\text { Pro } \\
\text { pemberitaan } \\
\text { begal pada } \\
\text { rubrik } \\
\text { kriminal } \\
\text { Wartabromo. } \\
\text { com } \\
\text { Kontra } \\
\text { pemberitaan } \\
\text { begal pada } \\
\text { rubrik } \\
\text { kriminal } \\
\text { Wartabromo. } \\
\text { com } \\
\text { Netral } \\
\text { pemberitaan } \\
\text { begal pada } \\
\text { rubrik } \\
\text { kriminal } \\
\text { Wartabromo. } \\
\text { com }\end{array}$ \\
\hline 3. Intensitas & $\begin{array}{c}\text { Terdapat } 3 \text { kalimat : } \\
>\text { Kuat } \\
>\text { Sedang } \\
>\text { Lemah }\end{array}$ \\
\hline
\end{tabular}

(Sumber : hasil kajian penulis 2018)

Unit analisis dan kategorisasi pada tabel di atas adalah acuan peneliti dalam melakukakan penelitian ini. Diharapkan bahwa unit analisis dan kategorisasi tersebut dapat diaplikasikan sebagai pedoman penelitian untuk mengetahui kecendrungan opini masyarakat Kota Pasuruan Tentang Berita Begal Pada Rubrik Kriminal Wartabromo.com.

\section{Teknik Pengambilan Data}

\section{Wawancara}

WawancaramenurutSugiyono(2013:317)

adalahpertemuanduaorang

untukbertukarinformasi

danidemelalui

tanyajawab,sehinggadapat

dikostruksikanmaknadalam suatutopiktertentu. Wawancaradilakukansecaramendalam

danterstrukturkepadasubjek penelitian dengan pedomanyangtelah dibuat,setiapresponden diberi pertanyaanyangsamadanpengumpuldatamencatat nya. Wawancara pada penelitian ini ditujukan kepada masyarakat Kota Pasuruan yang mengetahui pemberitaan online Wartabromo.com 


\section{Dokumentasi}

Menurut Arikunto (2010:274) dokumentasi yaitu mencari data mengenaihal-hal atauvariabelyangberupacatatan,transkrip,buku, suratkabar,majalah,prasasti,notulen

rapat,lengger,agendadan sebagainya.Studi dokumentasimerupakan pelengkapdaripenggunaan metodeobservasidanwawancaradalampenelitiank ualitatif. Dalam penelitianini,studi dokumentasi yang dilakukan olehpeneliti adalah denganmengumpulkandatamelalui sumbersumbertertulis.

Peneliti mengumpulkan data dari dokumen yang sudah ada, sehingga penulis dapat memperoleh catatan-catatan yang berhubungan dengan penelitian ini, seperti : gambaranumum wartabromo.com, struktur organisasi wartabromo.com, foto-foto dan sebagainya. Metode dokumentasi ini dilakukan untuk mendapatkan data-data yang belum didapatkan melalui metode wawancara.

\section{Teknik Analisis Data}

Setelahmendapatkandatayangdiperolehmelal uiwawancara dandokumentasimakatahapselanjutnyaadalahmela kukananalisisdata. Teknik analisa data dalam penelitian ini adalah teknik analisa model interaktif yang dikembangkan oleh Miles dan Huberman (1992:15). Teknik analisis data model interaktif berlangsung dalam tiga tahap berikut.

\section{a. ReduksiData}

Reduksi data dimaksudkan untuk menyusun data hasil observasi ke dalam bentuk uraian secara langkap dan rinci. Kemudian kepadanya dilakukan reduksi atau pemilihan data yang berkaitan dengan pokok penelitian dengan tujuan untuk mendapatkan data pokok atau penting yang hanya berkaitan dengan permasalahan penelitian. Reduksi data dilakukan secara terus-menerus selama penelitian berlangsung sehingga dapat disusun hasil penelitian secara lengkap.

\section{b. PenyajianData}

Penyajian data (display data) dibuat guna memudahkan peneliti dalam melihat keseluruhan data. Dalam penelitian ini, penyajian data disusun dalam bentuk teks naratif (kumpulan kalimat) yang dirancang guna mengabungkan informasi yang tersususun dalam bentuk yang mudah dibaca atau diinterprestasikan. Dengan cara ini peneliti dapat melihat apa yang sedang terjadi dan dapat menarik kesimpulan secara cepat.

\section{c. Penarikan Kesimpulan danVerifikasi}

Penarikan kesimpulan dilakukan secara terusmenerus sepanjang proses penelitian, dan verifikasi dilakukan guna perbaikan dan pencocokan data secara terus- menerus selama proses penelitian berlangsung ${ }^{25}$. Pada penelitian ini, kegiatan pengumpulan data, reduksi data, penyajian data, penarikan kesimpulan dan verifikasi merupakan suatu siklus kegiatan yang interaktif dan komprehensif yang dilakukan secara teliti dan rinci sehingga diperoleh hasil penelitian yang akurat. Secara skematis analisis data penelitian melalui proses pengumpulan data, reduksi data, sajian data, dan verifikasi data dapat dilihat pada gambar berikut.

\section{Skema Teknik Pengumpulan Data}

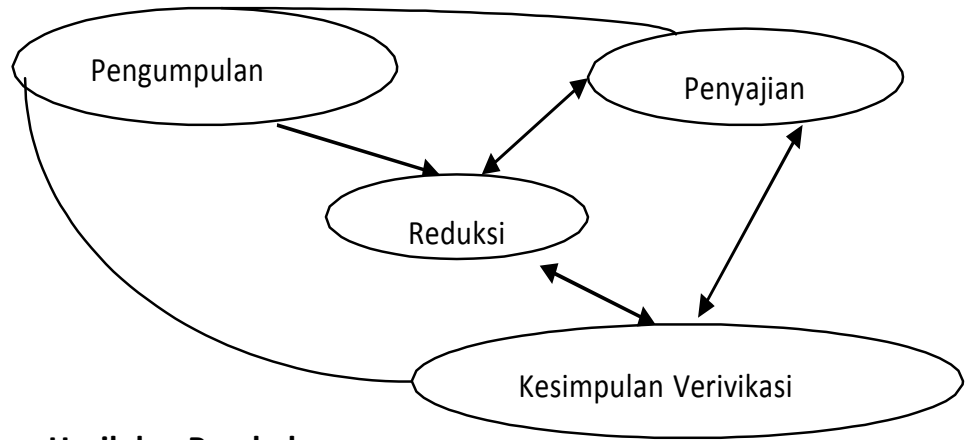

Hasil dan Pembahasan

Masalah kriminalitas apalagi pembegalan selalu menarik perhatian wartawan maupun membaca. Karena itu hampir setiap media pemberitaan baik itu media elektronik maupun media cetak selalu ada rubrik tentang kriminalias. Media massa merupakan salah satu bentuk komunikasi massa, dimana komunikator berhadapan (secara tidak langsung) dengan komunikan (massa/"masyarakat" pembaca).

Dalam persolan ini tentunya akan membentuk Opini terhadap pemberitaan tersebut, hal ini juga terjadi pada pemberitaan begal yang ada pada rubric kriminal wartabromo.com yang mana media tersebut terus-menerus memuat pemberitaan tentang begal di Pasuruan, yang akhirnya menarik masyarakat untuk membentuk opini terhadap pemberitaan tersebut. Proses pembentukan opini publik yaitu penyesuaian opini pribadi tiap-tiap individu dalam satu kesamaan persepsi tentang opini tersebut. Pada akhirnya, kesamaan persepsi masyarakat Kota Pasuruan merupakan opini publik yang merepresentasikan pemberitaan begal pada rubrik kriminal wartabromo.com.

Dari 79 berita begal pada rubrik krikminal Wartabromo.com periode Januari 2017 - Januari 2018 telah penulis ringkas dan di kategorisaskan meliputi berita pembegalan sadis, begal di keroyok massa, penangkapan \& tembak ditempat yang akan penulis sajikan bersamaan dengan Opini 
Masyarakat Kota Pasuruan terhadap pemberitaan tersebut sebagai berikut :

\section{a. BERITA PEMBEGALAN SADIS}

\begin{tabular}{|c|c|}
\hline TANGGAL & JUDUL BERITA \\
\hline 14 Agust 2017 & $\begin{array}{l}\text { Lengan Polisi Ini Ditebas } \\
\text { Begal Dengan Celurit, } \\
\text { Saat Lakukan Pengejaran }\end{array}$ \\
\hline 14 Maret 2017 & $\begin{array}{l}\text { Sopir Rental Pikap } \\
\text { Dibegal dan Dibacok di } \\
\text { Winongan }\end{array}$ \\
\hline 1 Februari 2017 & $\begin{array}{l}\text { Liburan Bulan Madu, } \\
\text { Pasutri Dibacok Begal Di } \\
\text { Jalur Wisata Bromo }\end{array}$ \\
\hline 29 Januari 2017 & $\begin{array}{l}\text { Bacok Korbannya, Ini } \\
\text { Kronologis Dua Begal } \\
\text { Motor Tewas Ditangan } \\
\text { Warga }\end{array}$ \\
\hline 20 Januari 2018 & $\begin{array}{l}\text { Ditebas Begal Berkali-kali, } \\
\text { Marinir Ini Tak Terluka }\end{array}$ \\
\hline
\end{tabular}

\section{b. BERITA BEGAL DI MASSA WARGA}

\begin{tabular}{|l|l|}
\hline TANGGAL & JUDUL BERITA \\
\hline \multirow{2}{*}{23 Feb 2017 } & $\begin{array}{l}\text { Dimassa Warga, Begal } \\
\text { Motor Ini Kepalanya } \\
\text { Remuk dan Motornya } \\
\text { Dibakar } 2017\end{array}$ \\
\hline 23 Feb 2017 & $\begin{array}{l}\text { Dua Begal Motor asal } \\
\text { Pasuruan Tewas Dihajar } \\
\text { Massa di Sidoarjo }\end{array}$ \\
\hline & $\begin{array}{l}\text { Ini Video Amuk Massa } \\
\text { Terhadap Begal di Nguling } \\
\text { Pasuruan }\end{array}$ \\
\hline
\end{tabular}

c. BERITA PENANGKAPAN BEGAL DAN TEMBAK DI TEMPAT

\begin{tabular}{|c|c|}
\hline TANGGAL & JUDUL BERITA \\
\hline 10 April 2017 & $\begin{array}{l}\text { Polisi Tembak Pelaku } \\
\text { Begal Bermotor Honda } \\
\text { Beat Putih di Wonoasih }\end{array}$ \\
\hline 6 Maret 2017 & $\begin{array}{l}\text { Begal Honda Jazz asal } \\
\text { Sapulante } \quad \text { Pasrepan } \\
\text { Ditembak Kakinya }\end{array}$ \\
\hline 19 Feb 2017 & 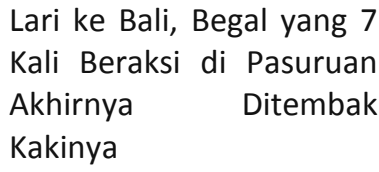 \\
\hline 22 Januari 2018 & $\begin{array}{l}\text { Tim Sakera Bekuk Dua } \\
\text { Begal Sadis di Pasuruan }\end{array}$ \\
\hline
\end{tabular}

Objek yang ditemui peneliti mengungkapkan bahwa kejahatan begal yang ada di Pasuruan ini sudah tidak asing lagi ditelinga mereka. Hampir dari semua objek yang sudah ditemui mengungkapkan bahwa kejahatan begal ini terjadi karena ada masalah faktor ekonomi dan minimnya pendidikan.

\section{Pembahasan Berdasarkan Karakteristik Opini Publik}

Menurut Dan Nimmo dalam (Riswandi:2009) Berdasarkan tahapan pembentukkan opini publik, karakteristik opini publik dapat dijabarkan sebagai berikut:

\section{Hasil Analisis}

\begin{tabular}{|c|c|}
\hline Unit Analisis & Kategorisasi \\
\hline a. Isi Opini & $\begin{array}{l}\text { Hasil penelitian berdasarkan } \\
\text { karakteristik opini publik dengan } \\
\text { kategori isi opini dapat } \\
\text { disimpulkan bahwa enam dari } \\
\text { sepuluh informan masyarakat } \\
\text { Kota Pasuruan tersebut } \\
\text { cenderung berupa pujian dan } \\
\text { harapan. Artinya pemberitaan } \\
\text { begal pada rubrik kriminal } \\
\text { Wartabromo.com memberikan } \\
\text { efek positif kepada masyarakat } \\
\text { dan menjadikan masukan untuk } \\
\text { pihak pemerintah bahwa wilayah } \\
\text { Pasuruan saat ini masih jauh dari } \\
\text { kata aman. }\end{array}$ \\
\hline b. Arah Opini & 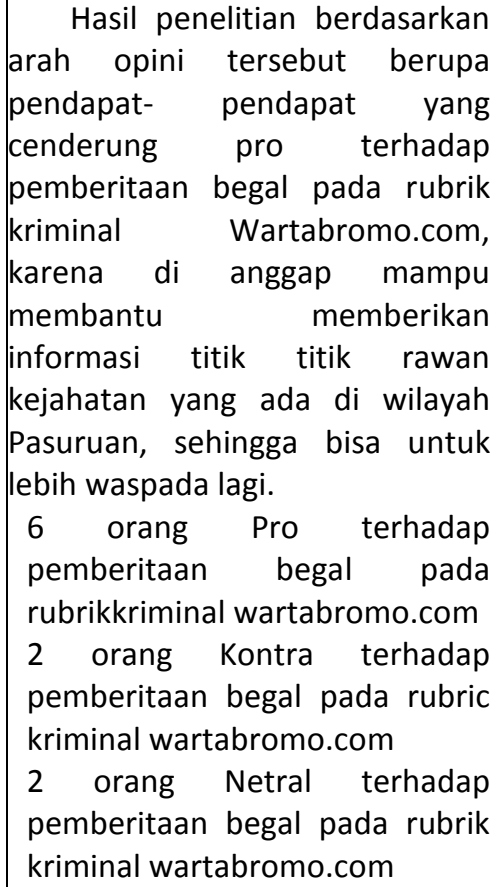 \\
\hline
\end{tabular}




\begin{tabular}{|c|c|}
\hline c. Intensitas & 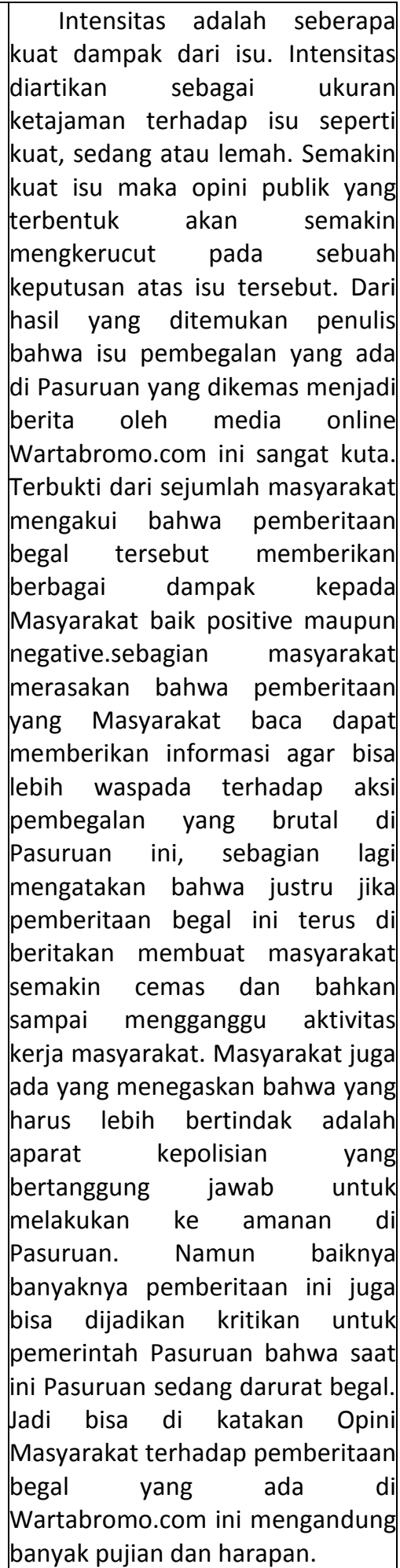 \\
\hline
\end{tabular}

\section{KESIMPULAN}

Dari penelitian dan analisis di atas maka dapat ditarik kesimpulan yaitu sebagai berikut :

1. Masyarakat Kota Pasuruan ber opini bahwa kejadian begal yang saat ini sedang marak di wilayah Pasuruan sangat meresahkan dan menghambat aktivitas mereka, mereka menegaskan bahwa untuk menghapus kejahatan ini harus dari akarnya, yakni kemiskinan dan pendidikan, maka mereka memberikan masukan terhadap pemerintah setempat agar memberikan pembinaa sejak dini kepada para pelaku pembegalan yang notabenya masih sekolah. Mereka juga menegaskan bahwa perlu adanya kerjasama antara tokoh Masyarakat dan aparat kepolisian untuk menjadikan Pasuruan aman.

2. Berdasarkan hasil pembahasan maka dapat disimpulkan bahwa opini Masyrakat Kota Pasuruan terhadap berita begal pada rubrik Wartabromo.com cenderung positif (Pro) hal ini di buktikan dengan, pertama isi opini, pendapat mereka cenderung pro terhadap pemberitaan begal tersebut. Kedua arah opini, pendapat mereka cenderung pro terhadap berita begal pada rubrikkriminal Wartabromo.com. ketiga intensitas, ketajaman issue masyarakat kota Pasuruan pada kasus pembegalan sangat kuat. Selain itu diharapkan pemberitaan yang terus menerus diberitakan ini mampu memberikan kritikan terhadap pemerintah bahwasannya Pasuruan saat ini sangat jauh dari kata aman.

\section{SARAN}

Dari penelitian mengenai analisis opini masyarakat Kota Pasuruan terhadap berita begal pada rubric criminal Wartabromo.com ini peneliti memiliki saran sebagai berikut :

1. Untuk Masyarakat Kota Pasuruan diharapkan untuk lebih aktif membaca pemberitaan, khususnya pemberitaan begal hal ini di karenakan pemberitaan merupakan sumber yang kaya akan informasi.Dari pemberitaan tersebut tentunya akan membuat kita lebih mengetahui lagi titik-titik rawan pembegalan yang ada di Pasuruan.

2. Untuk media online wartabromo.com untuk bisa konsisten dalam menjadikan wadah berbagi pengetahuan bagi parapembacanya. Sehingga media Wartabromo.com dapat lebih dikenal Masyarakat sebagai media online lokal yang berkualitas dan memicu opini yang positif dari Masayarakat. 
DAFTAR PUSTAKA

Azwar. Syaifuddin. 2013. Metode Penelitian. Yogyakarta : Pustaka Pelajar.

Arikunto, S. 2010. Prosedur Penelitian Suatu Pendekatan Praktik. Jakarta : Rineka Cipta

Ardianto, Soemirat Soleh Prof, DR, M.S. 2010. Dasar-dasar Public Relation. Bandung :PT Remaja Rosdakarya

Cangara, Hafied. 2006. Pengantar IImu Komunikasi. Jakarta : Raja Grafindo Persada.

Djuroto, Totok. 2002. Manajemen Penerbitan Pers. Bandung : PT Remaja Rosdakarya

Effendy, Onong Uchajana. 2001. Ilmu Komunikasi Teori dan Praktek, Bandung : Remaja Rosdakarya

MelvinL., De Fluer \&Sandra Ball-Rokcach.Theoryof Mass Communication.

Moleong,JLexy,Prof.Dr.2009,MetodePenelitianKual itatif.Bandung:PT.

RemajaRosdakaya

Nurudin. 2010. Pengantar Komunikasi Massa. Yogyakarta: Pustaka Pelajar

Olli, Helena dan Novi Erlita. Opini Publik. PT Indeks, jakarta, 2011

Rakhmat,Jalaluddin.1991.MetodePenelitianKomuni kasi.Bandung:PTRemaja

Rosdakarya.

Rakhmat, Jalaludin. Psikologi Komunikasi, PT Remaja Rosdakarya, Bandung,2001.

Rivers, William L. 2004.Media Massa dan Masyarakat Modern. Kencana:Jakarta

Riswandi. 2009. Ilmu Komunikasi Politik. Jakarta : Graha IImu

Ruslan, Rosady. 2008. Manajemen Public Relation \& Media Komunikasi. Jakarta : PT Rajagrafindo Persada

Selltiz, C.L., (et.al.), Research Methode in Social Relation, Newyork: Holt, Rinehart, and Winston, 1964.

Sugiyono. 2013. Metode Penelitian Kuantitatif Kualitati dan $R \& D$. Bandung : Alabeta.
Wartabromo companyprofile http://www.wartabromo.com/company-profil/

Yunus, Syarifuddin. 2010. Jurnalistik Terpaan. Bogor : Ghalia Indonesia 